\title{
INFRASTRUCTURE DEVELOPMENT \\ AS A CONDITION FOR IMPROVING THE MECHANISM OF INNOVATIVE ACTIVITY STIMULATION \\ (ON THE EXAMPLE OF SOUTHERN FEDERAL DISTRICT SUBJECTS)
}

\author{
Nadezhda Nikolaevna Lebedeva \\ Doctor of Economic Sciences, Professor, \\ Department of Economic Theory and Economic Policy, \\ Volgograd State University \\ lebvolgograd@rambler.ru,htes@volsu.ru \\ Prosp. Universitetsky, 100, 400062 Volgograd, Russian Federation \\ Irina Sergeevna Averina \\ Candidate of Economic Sciences, Assistant Professor, Department of Economic Theory and Economic \\ Policy, Volgograd State University \\ averina-irina@mail.ru,htes@volsu.ru \\ Prosp. Universitetsky, 100, 400062 Volgograd, Russian Federation
}

\section{Yuliya Vladimirovna Zadorozhneva}

Candidate of Economic Sciences, Assistant Professor,

Department of Economic Informatics and Management,

Volgograd State University

j_zadorozhneva@mail.ru, econinform@volsu.ru

Prosp. Universitetsky, 100, 400062 Volgograd, Russian Federation

\begin{abstract}
The article discusses the concept of the mechanism of innovative activity stimulation, which represents a system consisting of actors with their goals; formal regulations (legislation); informal regulations and rules (business culture, adopted by the economic community); incentives and constraints (economic and non-economic in nature). The authors specify the understanding of infrastructure as a condition of the mechanism functioning, compare rating assessments (by the NAIDIT technique) of innovation activity of subjects of the Southern Federal District (SFD) and reveal significant inconsistencies. The comparative analysis of the main existing infrastructure elements of the innovation sphere (Krasnodar, Volgograd and Rostov regions) let make conclusions about their sufficiency or insufficiency in different subjects of the macro-region. The negative trends of innovative infrastructure development include: the lack of a unified information and analytical database and system for the promotion and support of innovative projects; the lack of consolidated data to assess the development level of the regional innovative infrastructure in formal source; the failure and the need for development elements, such as clusters and science-technology parks, support funds and the creation of extensive networks of centers for collective use. Directions of improvement of innovation activity are presented on the basis of comparing its peculiar indicators as well as analyzing and identifying missing infrastructure elements of the innovation system (scientific
\end{abstract}


and investment, information and analytical, organizational and communicative) with the aim of increasing the efficiency of existing mechanisms of innovation stimulation in the regions. Scientific and practical significance of this work consists in the future use of its provisions and conclusions as additional theoretical and methodological substantiation of scientific developments in research of innovative activity stimulation, and also for its improvement in innovation policy of public authorities on defining the strategic priorities for regional development.

Key words: infrastructure, infrastructure elements, mechanism, stimulation, innovative activity, problems, prospects.

At present, competitiveness of economy as a whole and its individual regional components depend on the level of its innovation development. Therefore the growing interest of researchers for studying the conditions, factors and mechanisms of development of innovation is relevant, and there is obvious demand for practice in this phenomenon. Thus, investigation and search for ways of improvement innovation infrastructure as a set of elements influencing increase innovation activeness of business entities through the creation organizational-economic conditions, is an important element on the way to solving problems arising in innovative sphere. This understanding leads to necessity of studying mechanisms stimulation of innovative activity, both at the level of a particular region, and in the country as a whole.

The objective of this work is to identify relevant directions of infrastructure improvement, which is considered as a condition for efficiency enhancement of the mechanism stimulation innovative activity of economic entities in the framework of the macro-region (on the example of the SFD).

It is advisable to start our research with the study of the term of economic mechanism as the basis for study in phases following the evolution of this category is to identify its interrelation and interdependence with the institutional mechanism.

Initially the term "mechanism" was borrowed from the technical sphere and it was firmly entrenched in the economic turnover, thanks to scientific works on the economy of socialism in the second half of the 1960s.

"Steady-state" definitions characterize the category "mechanism", firstly, as "a set of conditions and processes that make up homeostasis phenomenon (stationary); it represents the processes of adaptation and development, bringing the system to the corresponding states" [6]; secondly, as "internal structure (the system of links) machine, appliance, apparatus, leading them in action", and "system, a device that determines the order of any kind of activity" [26, p. 352].

The term "mechanism", despite the fact that initially it has a physical nature and it owes its appearance exactly to technical sphere, is interpreted in several ways - as a technical term, as a philosophical and economic categories ("business mechanism", "economic mechanism", "institutional mechanism").

Continuing the study of the basic category "mechanism", it is advisable to give the domestic scientist opinion, Y.M. Osipov's, which interprets the term as "a system of organization system" $[25$, p. 22] and he notes that "the mechanism of the system is complex, as complex and the system itself" [25, p. 23], because it "is a set of mechanisms, i.e. sub mechanisms" [25, p. 23]. Next, Y.M. Osipov notes that "the mechanism has a purpose to organize something, and this purpose should be achieved", showing thereby its essence "the purpose plus a purpose achievement (the amount of necessary patterns and qualities). The purpose achievement - implementation of the mechanism, the coincidence of the purpose and result - reality of the mechanism...., purpose action - result - purpose it is the integrity of the mechanism, its isolation on itself' [25, p. 24].

The mechanism stimulation, in turn, can be defined as a procedure (rule) of the adoption by the governing body decisions about the motives of managed entities to commit the required actions [22, p. 9].

According to the general definition of economic stimulation [3], it is possible to provide the mechanism stimulation of innovative activity as a set of economic measures that will contribute to economic actors who have intensified their activities in the innovative sphere.

The mechanism stimulation of innovative activity is a system consisting of: entities having 
their goals; formal regulations (legislation); informal norms and rules (business culture, adopted within the economic community); incentives and disincentives (economic and non-economic). At that infrastructure in the innovation sector will be considered as a set of conditions that affects efficiency of functioning of the mechanism stimulation.

There are various definitions of innovation infrastructure in modern literature, we highlight the most capacious of them.

By Federal legislation innovation infrastructure is defined as "a set of organizations that provide services for the creation, production and (or) practical application of new or improved product, new or advanced technological process" [10]. However, this definition makes no assumptions about the detailed structure of the elements included in the innovative structure.

National centre for monitoring the innovation infrastructure of scientificand technical activity and regional innovation systems offers a more detailed definition. The infrastructure of the national innovation system is a set of conditions (such as fundamental science and the education system), organizations, industrial facilities, which provide the opportunity of successful innovation [19]. However, this definition does not take into account the existing relationships between actors in the innovation process, which create and generate new knowledge, transform them into new products, and ensure their distribution and consumption. In fact, innovation infrastructure is a link between the results of scientific research with the business sector of the economic system.

Information and consulting centers, scientifictechnological parks, technology transfer centers, business incubators, clusters, universities, centers of collective use, scientific research centers and technology companies, financing centers are the basis of infrastructure in the innovative sphere. Let us consider each of the selected elements.

Information and consulting centers are a set of specialized institutions that provide system solutions in the innovative sphere, by providing for the protection of information; support of innovative projects; training and retraining; and automation of business processes [31].

Scientific and technological parks are the following selection elements, which represent the research-production-territorial complexes, the purpose of which is to ensure the most favorable conditions for development of small and mediumsized innovative enterprises [2].

The technology transfer centers are institutions capable of commercializing the results of scientific research through the creation of small high-tech enterprises and license agreements [32].

Technoparks, in turn, represent complexes, providing "a variety services to firms-innovators in various stages of commercial development of scientific knowledge, know-how and technology" [12].

Business incubators are also multifunctional complexes, providing a variety of services to new innovative companies that are at the stage of creation or formation. Functional orientation of incubators, as elements of the innovation infrastructure, is in the process of providing assistance to innovative companies in the early stages of their development. Concepts of technology parks and business incubators are close to their functional content, however, it is worth noting the existing difference between them: "the parks are not peculiar to the strict policy of constant renewal, rotation clients, typical for incubators in the field of innovative activity" [2].

We should also highlight the business incubators at universities, the purpose of which is to prepare projects by scientists to further "create university enterprises, or for the implementation of these projects on the basis of the partner organizations of the university" [23].

The main tasks of the selected element of the infrastructure are as follows: creation of favorable conditions for effective commercialization of innovative developments; training and retraining of personnel of small innovative enterprises at the stage of formation; the promotion and presentation of prospective projects for exhibitions; assistance in development of business plans and preparation of bid documents, and accounting, and intellectual property protection.

The next element of the innovation infrastructure is the cluster, the results of which are innovative goods and services. "Achieved in clusters synergy innovation depends on their institutional arrangements and is the result of collective action, based on collaboration" [7].

Small enterprises at universities, which are an important element of economic development of individual regions. The creation of small innovative enterprises (SIE) on the basis of the university 


\section{РЕГИОНАЛЬНАЯ ЭКОНОМИКА}

provides a number of advantages, among which particularly stand out, such as: additional sources of financing the activities of the university; to promote scientific activity of university staff; improving the image of higher education institutions, etc. The purpose of creating SIEs at universities is to obtain commercial benefits from the implementation of projects based on them.

The role of small innovative enterprises in the creation of an effective regional innovation systems is that they contribute to the development of scientific-technical potential and promotion of the results of scientific-research and experimentaldesign works in the real sector economy of the region. "SIE is capable to very rapidly and flexibly respond to changes in consumer demand and new proposals and future opportunities based on results of research and development; bringing scientific knowledge to industrial production (experimentaldesign, test works, pilot production within SIE); production of high-tech product on stand-alone basis or in conjunction with other organizations (large, medium and small business, including government contracts, other SIE). The development mechanisms of innovative interaction between SIE and big business is possible on the basis of outsourcing; the organization of additional jobs, including for highly qualified specialists, researchers, students, graduates, able to work in the search condition, as new scientific solutions, and financial capacities for the implementation of scientific and technical achievements in all sectors of the economy; the actualization of the role of innovator in society and, above all, among young people; ensuring effective communication between the individual elements of the innovation system of the region" [21].

Universities, being one of the basic elements of innovation infrastructure, concentrate intellectual, informational, and material resources.

The centers of collective use are the next element of the innovation infrastructure, which are institutions that provide a range of services and the possibility of using new technologies in production through collective use of equipment.

RUSNANO defines the Center of collective use as "a research center, equipped with special equipment, involving sharing of resources such center" [27].

There is a more extended definition of the Center of collective use (CCU) of scientific equipment, which is a "property complex (usually on the basis of higher educational or research organizations), providing a mode of collective use of precision of expensive scientific and technological equipment, basic structural units of the organization, as well as third-party users" [28].

Research-and-production centers (RPC) and technology companies are enterprises, which are oriented to comprehensive implementation and promotion of innovative projects, technologies and equipment, including their own development in the interests of the power ministries and agencies, and enterprises telecommunications and fuel and energy industries.

The main objectives of the RPC are:

- the formation of "complexes and objects of communication stationary and mobile versions of execution of projects;

- design and manufacture integrated multifunctional mobile communication systems (communication nodes, centers and control centers, video conferencing and video surveillance, command and staff vehicles, integrated communication hardware and other moving objects special purpose) on different types transport base of domestic and import production, including reservation base, surface and air objects;

- design and manufacture integrated multifunctional rapidly deployed container communication systems (nodes communication, centers and control centers, video conferencing and video monitoring, integrated communication hardware);

- the education and training of specialists for competent operation of the supplied machinery and equipment;

- ensuring product compliance with existing regulations and technical documents, including national and international standards" [29].

The centers of funding, as element of the innovation infrastructure, are presented by the business angels. These organizations allocate investment funds for innovative companies at the earliest stages of development (planting and initial). "The volume of business angel investments in one company can be from tens of thousands up to a million euros" [9].

Business angels use "venture investment mechanism, under which the funding is long-term (3-7 years), without collateral and guarantees, for a share (shares) in the company" [5]. Reducing the 
risks of venture capital investment is by investing in several companies at a time, careful review and selection of projects, participation in business management. The effectiveness of such investment is achieved through the formation of the necessary relationships between investors, innovators and managers. Thus, business angels are not only investing in the company, but pass on the experience and business relationships in the implementation of innovative projects. The objective of the business angels' investment in innovative projects is "therising cost companies invested by them through the development and promotion of high-tech products on the market" [24]. The business angel receives the main income from the sale of its shareholding at a price higher than the initial investment.

Funds to support innovation (FSI) is a nonprofit organization created to strengthen the scientific-technical and innovation activities. Such funds are focused on implementing several directions:

- promote innovative ideas by expert evaluation;

- organization and carrying competition of innovation projects;

- assistance in preparation of feasibility studies and business plans of innovative projects, development of financing schemes;

- expertise in project management at all stages of their implementation;

- organization of educational programs in the field of innovation management;

- promotion of foreign economic activity of innovative enterprises (export, international economic cooperation and others);

- representation of participants interests of innovative projects in the state organizations [4].

Thus, the present elements of the innovation infrastructure is a necessary condition for effective operation of the mechanism stimulation of innovative activity of economic entities.

Purpose of the mechanism stimulation of innovative activity is creation of the conditions that contribute to enhancing innovation by using the economic instruments, as well as creating some infrastructure elements for efficiency enhancement of the system stimulation of economic entities in this sphere.

When creating the mechanism stimulating innovative activity in the special macroregion and definition the subjects of action it is advisable to analyze the innovation activity at each territorial subject under a separate district. In this case, for the analysis we have chosen the Southern Federal District.

In the framework of research by the National Association of innovations and information technologies development (NAIDIT), we made up ratings of innovation activity of the subjects of the Russian Federation (RF) in 2009-2013 based on the estimation of regional innovation indexes (Table 1).

Based on the analysis of the data obtained by NAIDIT, it follows that the Volgograd region in 2009-2010 occupied the 4th position in the macroregion (Southern Federal District), the Krasnodar region was 2nd and 1st, respectively. In the period of 2011-2013 the Volgograd region was fixed at the $3 \mathrm{rd}$ position in the Southern Federal District (to improve their performance in General, according to the national rating of a NAIRIT). At the same period, the Krasnodar region significantly improves its position (according to the national rating) moving up 17 positions (from $23 \mathrm{rd}$ and 21 st positions (2011 and 2012) to the 4th one (2013)). Other subjects of the Southern Federal District (Astrakhan region, Republic Adygea and Republic Kalmykia) changed insignificantly their positions. Such differences in

Table 1

The rating of innovation activity of subjects of the macroregion (on the example of the SFD)

\begin{tabular}{|l|c|c|c|c|c|}
\hline Method & \multicolumn{5}{|c|}{ NAIDIT } \\
\hline Year & 2009 & 2010 & 2011 & 2012 & 2013 \\
\hline The subjects of the Russian Federation: & \multicolumn{5}{|c|}{ Rank } \\
\hline Astrakhan region & $45(3)$ & $53(3)$ & $50(4)$ & $51(4)$ & $46(4)$ \\
\hline Volgograd region & $56(4)$ & $55(4)$ & $37(3)$ & $32(3)$ & $35(3)$ \\
\hline Krasnodar region & $41(2)$ & $32(1)$ & $23(1)$ & $21(1)$ & $4(1)$ \\
\hline Rostov region & $34(1)$ & $33(2)$ & $36(2)$ & $31(2)$ & $26(2)$ \\
\hline Republic of Adygea & $66(5)$ & $78(5)$ & $70(5)$ & $69(5)$ & $76(5)$ \\
\hline Republic of Kalmykia & $78(6)$ & $79(6)$ & $79(6)$ & $81(6)$ & $82(6)$ \\
\hline
\end{tabular}
$[11 ; 18]$.

Note. Figures in brackets show the rating of subjects in the SFD. Source: compiled by the authors based on 
the positions occupied by the Krasnodar region in 2009 and dramatically changed in 2013 and subsequent years, it is quite obvious, due to "Olympic investment boom".

Analysis of the conditions of innovative activity implementation in the above mentioned subjects will allow us to identify key conditions that activate or, on the contrary, "inhibit" innovation development in the regions.

Firstly we identify the elements of innovation infrastructure, typical for the Krasnodar, Volgograd and Rostov regions, as leaders in the rating of innovative development among the subjects in the SFD. We take the Rostov region for "the standard", as according to the rating, it can be classified as the most stable from the point of view of innovative development (1st-2nd positions for 5 years) (Table 2).

As we see, a large number of infrastructural objects operate on the territory of investigated subjects of the SFD. However, its set in each subjects of the macro-region is characterized by certain specifics. For example, the Rostov region seems to be the most developed, because it includes the whole list of elements and is characterized by effectively established relationships between them. In turn, the Krasnodar region also has well-developed

Comparative analysis of the main infrastructure elements in innovation sphere

\begin{tabular}{|c|c|c|c|}
\hline Elements & Rostov region & Volgograd region & Krasnodar region \\
\hline $\begin{array}{l}\text { Information } \\
\text { and } \\
\text { consulting } \\
\text { centers }\end{array}$ & $\begin{array}{l}\text { 1. Information consulting } \\
\text { center. } \\
2 \text {. Presentation and exhi- } \\
\text { bition fair }\end{array}$ & $\begin{array}{l}\text { 1. The consulting centre } \\
\text { "Expertise". } \\
\text { 2. Volgograd center for } \\
\text { patent services }\end{array}$ & $\begin{array}{l}\text { Office intellectual proper- } \\
\text { ty (Chamber of Com- } \\
\text { merce and industry in the } \\
\text { Krasnodar region) and } \\
\text { ACG SICC }\end{array}$ \\
\hline $\begin{array}{l}\text { Scientific- } \\
\text { technological } \\
\text { parks }\end{array}$ & $\begin{array}{l}\text { 1. "Taganrog". } \\
\text { 2. "InTech-Don". } \\
\text { 3. Media technology Park }\end{array}$ & Creation is planned & $\begin{array}{l}\text { Scientific-technological } \\
\text { Park at the Kuban state } \\
\text { University }\end{array}$ \\
\hline $\begin{array}{l}\text { The } \\
\text { technology } \\
\text { transfer } \\
\text { centers }\end{array}$ & $\begin{array}{l}\text { 1. European Association } \\
\text { of technology transfer, } \\
\text { innovation and industrial } \\
\text { technologies. } \\
\text { 2. SRSTU (NPI) }\end{array}$ & $\begin{array}{l}\text { Volgograd Centre for } \\
\text { technology transfer }\end{array}$ & $\begin{array}{l}\text { Regional technology } \\
\text { transfer centers }\end{array}$ \\
\hline Clusters & $\begin{array}{l}\text { Biotechnology, Biomedi- } \\
\text { cine and environmental } \\
\text { security, with } 5 \text { small in- } \\
\text { novative enterprises (SIE) }\end{array}$ & $\begin{array}{l}\text { Creation is planned (IT } \\
\text { and chemical- } \\
\text { pharmaceutical clusters) }\end{array}$ & $\begin{array}{l}\text { 1. Tourist. } \\
\text { 2. Creation of cluster agri- } \\
\text { cultural technologies devel- } \\
\text { opment is planned }\end{array}$ \\
\hline Universities & $\begin{array}{l}4 \text { innovation-oriented } \\
\text { Universities }\end{array}$ & $\begin{array}{l}2 \text { innovation-oriented } \\
\text { Universities }\end{array}$ & $\begin{array}{l}4 \text { innovation-oriented } \\
\text { Universities }\end{array}$ \\
\hline $\begin{array}{l}\text { The centers } \\
\text { of collective } \\
\text { use }(\mathrm{CCU})\end{array}$ & More than $20 \mathrm{CCU}$ & More than $10 \mathrm{CCU}$ & More than $10 \mathrm{CCU}$ \\
\hline $\begin{array}{l}\text { Business } \\
\text { incubators }\end{array}$ & $\begin{array}{l}4 \text { - with SIE on its territo- } \\
\text { ry }\end{array}$ & $\begin{array}{l}\text { Volgograd regional } \\
\text { business-incubator }\end{array}$ & $\begin{array}{l}\text { "Development" in the } \\
\text { Kropotkin city }\end{array}$ \\
\hline $\begin{array}{l}\text { Scientific } \\
\text { research cen- } \\
\text { ters and } \\
\text { technology } \\
\text { companies }\end{array}$ & $\begin{array}{l}\text { 1. Technological engi- } \\
\text { neering company. } \\
\text { 2. Center of space and } \\
\text { optoelectronic technolo- } \\
\text { gies }\end{array}$ & $\begin{array}{l}\text { 1. The group RUSNANO. } \\
\text { 2. The state Corporation } \\
\text { "Rostekhnologii". } \\
\text { 3. The center of protection } \\
\text { and business development } \\
\text { "Business" }\end{array}$ & $\begin{array}{l}\text { 1. Youth centre of innova- } \\
\text { tions. } \\
2 . \text { Krasnodar innovation } \\
\text { center }\end{array}$ \\
\hline $\begin{array}{l}\text { Financing } \\
\text { centers }\end{array}$ & $\begin{array}{l}\text { The agreement with the } \\
\text { Russian Association of } \\
\text { venture investments is } \\
\text { concluded (including } \\
76 \text { investors different le- } \\
\text { vels) }\end{array}$ & $\begin{array}{l}\text { 1. The Agency of invest- } \\
\text { ment development. } \\
\text { 2. Regional microfinance } \\
\text { center. } \\
\text { 3. } 9 \text { support Funds. } \\
\text { 4. "National fellowship of } \\
\text { business-angels", and net- } \\
\text { work "Private capital" }\end{array}$ & $\begin{array}{l}\text { 1. The Fund of promotion } \\
\text { development venture in- } \\
\text { vestments in small enter- } \\
\text { prises. } \\
\text { 2. Funds based on Open } \\
\text { corporation "RBC" }\end{array}$ \\
\hline
\end{tabular}

Note. Source: compiled by the authors based on $[13-17 ; 20 ; 30]$. 
infrastructure in innovation sphere, however, it has a smaller number of objects under each of elements. In the Volgograd region some infrastructure elements are absent, for example, clusters and scientific-technological parks, however, in the official sources there is information about its creation planned in the coming years. Unfortunately, in the Volgograd region only one technology transfer centre is created, while in other regions the network of centers is more extensive (for example, the Krasnodar region has a network of regional centers for transfer).

Infrastructure component in the selected regions of the SFD is quite developed, however consolidated statistical database, which would allow to track changes in number of infrastructure components and efficiency of its functioning in the mechanism stimulation innovation activity in regions, is absent, it is narrows the possibility of analysis and forecasting perspective changes.

Let us consider statistical data, which are formal reflection of efficiency of functioning innovation infrastructure (Table 3 ).

From the table data it follows, that the efficiency of functioning infrastructure complex in the Rostov region is quite high. According to the data by Rostovstat, innovative activity on the territory of the Rostov region is carried out by 145 organizations. For the last 7 years (2006-2012) the volume of shipped innovation products increased in almost 4 times and makes 34,7 billion rubles [1].

The exception is only ahead of Krasnodar region by the number of created innovative technologies, which have intensified through the point projects of "Olympstroy". At the same time, iwe can see the difference between indicators of shipped products volumes, performed by own forces. According to this indicator, the Rostov region outstrips the Krasnodar region in 13 times, Volgograd region - in 8 times.
From the analysis the innovation infrastructure of the subjects-leaders of the macroregion (the SFD), we can draw the following conclusions:

1. Existing infrastructure elements within the individual subjects of the SFD (Krasnodar, Rostov and Volgograd regions) are rather advanced, however weak interconnection and interaction between them are the source of low results innovation activity in separate regions.

2 . There are consulting centers that provide support to innovative projects and their promotion, but their network is not sufficiently extensive on the territory of the subjects.

3. There are positive trends in the development of infrastructure component as a condition of effective functioning of the mechanism stimulation of innovative activity, to strengthening the positions of some subjects of the macroregion in the allRussian rating testifies about this. The Rostov region occupies the 34th position in 2009, and the 31 st - in 2013; the Krasnodar region was 41st and 4th, and the Volgograd region was 56th and 35th, respectively.

At the same time, the analysis revealed some negative tendencies inherent in the development of innovation infrastructure:

- lack of unified information and analytical base and system of promotion and support innovative projects, both within a single macroregion and at the national level;

- lack of consolidated data for the assessment of development level of the regional innovative infrastructure on the official sites of Federal and territorial statistical bodies of the Russian Federation and the portals of the Executive authorities of the subjects, that creates a situation of information asymmetry and provokes the possibilities of adopting insufficiently verified solutions;

- failure and need for the development of such elements as clusters and science-technology

Main indicators of innovation activity in the subjects of the SFD in 2012

Table 3

\begin{tabular}{|l|c|c|c|c|}
\hline the SFD & $\begin{array}{c}\text { Costs on tech- } \\
\text { nological inno- } \\
\text { vation, thou- } \\
\text { sands rubles }\end{array}$ & $\begin{array}{c}\text { Used advanced } \\
\text { production } \\
\text { technologies, } \\
\text { units }\end{array}$ & $\begin{array}{c}\text { Created ad- } \\
\text { vanced produc- } \\
\text { tion technolo- } \\
\text { gies, units }\end{array}$ & $\begin{array}{c}\text { The volume of shipped in- } \\
\text { novation products, works } \\
\text { and services by own forces, } \\
\text { millions rubles }\end{array}$ \\
\hline Krasnodar region & 11458605,2 & 2261 & 16 & 3135,7 \\
\hline Volgograd region & 6843651,2 & 2055 & - & 5298,9 \\
\hline Rostov region & 18412041,3 & 2822 & 12 & 40543,1 \\
\hline
\end{tabular}

Note. Source: compiled by the authors based on [8]. 


\section{РЕГИОНАЛЬНАЯ ЭКОНОМИКА}

parks, support funds and the creation of an extensive network of Centers collective use CCU (Volgograd region).

Identified deficiencies necessitate adjustments to the existing approach of providing information for the evaluation of innovation activity of the regions and therefore they are disincentive mechanism of its motivation.

In the result of the conducted research and identified negative trends of development the region innovative infrastructure (as an element of the mechanism stimulation innovation activity) is useful to distinguish directions of its improvement, based on territorial peculiarities:

- scientific-investment: the creation of a unified informational-analytical base and mechanisms for the promotion and support of innovative projects at the macroregion and the country levels for attraction of investment funds;

- information-analytical: creation and introduction systems of complex monitoring and evaluation indicators of the development level of innovation infrastructure, the optimization of providing information to economic agents about development and use of innovations on the official sites of the subjects Russian Federation and statistical authorities;

- organizational-communication: modernization of the mechanism of stimulation innovation activity on the basis of transformation region's infrastructure to ensure the effectiveness of functional interrelations of its elements.

Cooperation in these directions, taking into account the socio-economic features of the region will create the necessary conditions of its resource availability and readiness to use its innovative potential.

Solution of the problems of improvement of the mechanism stimulation of innovation activity is one of the relevant and important areas of scientific and practical research. This is due to the necessity of its improvement by developing functional linkages between infrastructure elements, both at the level of a particular region, and in the country as a whole.

In the result of the conducted research the following tasks were solved:

- analysis of the status of the innovation activity of economic entities of the SFD has allowed to reveal positions of the regions as part of the overall ranking, both to macroregion and the country as a whole;
- review infrastructure as necessary condition for functioning of the mechanism innovation activity stimulation on the example of regions of the SFD led to identification elements and shortcomings of their structural and functional relationships;

- directions to improvement of the mechanism of innovative activity stimulation are proposed: scientific-investment, informationanalytical, organizational-communication. Scientific and practical significance of the work is presented in the further use of its provisions and conclusions as additional theoretical and methodological substantiation of scientific developments in research of mechanism of innovative activity stimulation, as well as for its improvement within the framework of the innovation policy state authorities when determining strategic priorities of regional development.

\section{REFERENCES}

1. Administratsiya Rostovskoy oblasti [Administration of the Rostov region]. Ofitsialnyy portal. Innovatsii [Official Portal. Innovations]. Available at: http://www.donland.ru/Default.aspx? pageid=80488. (accessed April 20, 2015).

2. Agentstvo po innovatsiyam i razvitiyu [The Agency for Innovation and Development]. Available at: www.innoros.ru/infrastructure/tekhnoparki. (accessed April 20, 2015).

3. Borisov A.B., ed. Bolshoy ekonomicheskiy slovar [Big Economic Dictionary]. Moscow, Book world Publishing House, 1999. 863 p.

4. Distantsionnyy konsalting. Fond podderzhki innovatsiy [Remote Consulting. The Innovation Fund]. Available at: http://www.distcons.ru/BOffers/BOfferShow.asp?ID=297531. (accessed April 20, 2015).

5. Dvizhenie "biznes-angelov" $i$ chastnoe investirovanie innovatsionnogo biznesa [The Movement of "Business Angels" and Private Investment of Innovative Business]. Available at: http: //www.businesspress.ru/newspaper/article_mId_3 aId_435764.html (accessed 20 April 2015).

6. Efremova T.S., ed. Sovremennyy tolkovyy slovar [Modern Explanatory Dictionary]. Available at: http://enc-dic.com/efremova/Mehanizm-45553. (accessed April 20, 2015).

7. Ekonomicheskaya politika (ekspertnyy kanal). Innovatsionnye klastery: mirovye orientiry $i$ rossiyskie realii [Economic Policy (Expert Channel). 
Innovative Clusters: Global Guidelines and the Russian Realities]. Available at: http: //ecpol.ru/2012-04-05-1341-25/2012-04-05-13-41-42/756-innovatsionnyeklastery-mirovye -orientiry-i-rossijskie-realii.html about. (accessed April 20, 2015).

8. Federalnaya sluzhba gosudarstvennoy statistiki [Federal State Statistics Service]. Available at: http://gks.ru about. (accessed April 11, 2015).

9. Federalnyy portal malogo i srednego predprinimatelstva. Finansirovanie innovatsionnogo proekta [Federal Portal of Small and Medium-Sized Business. Financing of the Innovative Project]. Available at: http://pmp.crpp.ru/content/articles/ startbusines/finance/m,40,1090 about. (accessed April 22, 2015).

10. Federalnyy zakon "Ob innovatsionnoy deyatelnosti i o gosudarstvennoy innovatsionnoy politike", prinyatyy Gosudarstvennoy Dumoy 1 dekabrya 1999 g., odobrennyy Sovetom Federatsii 23 dekabrya 1999 g. i otklonennyy Prezidentom Rossiyskoy Federatsii 3 yanvarya 2000 g. [The Federal Law “On Innovation Activity and on the State Innovation Policy" Adopted by the State Duma on December 1, 1999, Approved by the Federation Council on December 23, 1999 and declined by the President of the Russian Federation on January 3, 2000]. Available at: http://iam.duma.gov.ru/node/8/4582/ 15960. (accessed April 20, 2015).

11. Golberg L.M., ed. Reyting innovatsionnogo razvitiya subyektov Rossiyskoy Federatsii: analiticheskiy doklad [Rating of Innovative Development in the Subjects of the Russian Federation: Analytical Report]. Moscow, Vysshaya shkola ekonomiki Publ., 2012. 104 p.

12. Gosudarstvennaya innovatsionnaya politika [State Innovation Policy]. Available at: http:/ /www.rae.ru/monographs/112-3774. (accessed April 20, 2015).

13. Innovatsionnaya deyatelnost. Kubanskiy gosudarstvennyy tekhnologicheskiy universitet [Innovative Activity. Kuban State Technological University]. Available at: http://kubstu.ru/s-56. (accessed April 20, 2015).

14. Innovatsionnaya infrastruktura [Innovative Infrastructure]. Ministerstvo ekonomiki, vneshneekonomicheskikh svyazey $i$ investitsiy. Ofitsialnyy portal [Ministry of Economics, Foreign Economic Relations and Investments. Official Portal]. Available at: http://economics.volganet.ru/folder_9-H/Folder_11/ Folder-2/folder_1/. (accessed April 20, 2015).

15. Innovatsionnaya infrastruktura SGU [Innovative Infrastructure of Sochi State University]. Available at: http://www.sutr.ru/science/Innovation\%20inf. about. (accessed April 20, 2015).

16. Innovatsionnyy portal Rostovskoy oblasti [Innovative Portal of the Rostov Region]. Available at: http://novadon.ru/set_podderzhki.html?page=3. (accessed April 20, 2015).

17. Molodezhnyy tsentr innovatsiy i tekhnologiy "Inventum" ["Inventum" Youth Center of Innovations and Technologies]. Kubanskiy gosudarstvennyy agrarnyy universitet. Ofitsialnyy portal [Kuban State Agrarian University. Official Portal]. Available at: http:/ /mol-inventum.ru. (accessed April 20, 2015).

18. Natsionalnaya assotsiatsiya innovatsiy $i$ razvitiya informatsionnykh tekhnologiy [National Association of Innovations and Information Technology Development]. Available at: http:// www.nair-it.ru/news/.about (accessed April 23, 2015).

19. Natsionalnyy tsentr po monitoringu innovatsionnoy infrastruktury nauchno-tekhnicheskoy deyatelnosti $i$ regionalnyh innovatsionnykh sistem [National Centre for Monitoring the Innovation Infrastructure of Scientific and Technical Activity and Regional Innovation Systems]. Available at: http:// www.miiris.ru. (accessed April 20, 2015).

20. Nauka v Krasnodarskom krae [Science in the Krasnodar Region]. Ofitsialnyy portal ispolnitelnykh organov gosudarstvennoy vlasti Krasnodarskogo kraya [Official Website of the Executive Bodies of State Power in the Krasnodar Region]. Available at: http://krasnodar. ru/content/521/show/5596. (accessed April 20, 2015).

21. Nojbaujer H. Innovatsionnaya deyatelnost na malykh i srednikh predpriyatiyakh [Innovation Activity in SMEs]. Problemy teorii i praktiki upravleniya [Problems of Management Theory and Practice]. Available at: http://www.bizeducation.ru/ library/management/innov/8/noibauer.htm. (accessed April 20, 2015).

22. Novikov D.A. Mekhanizmy stimulirovaniya $v$ organizatsionnykh sistemakh [Incentive Mechanisms in Organizational Systems]. Moscow, IPU RAN Publ., 2003. 349 p.

23. Novosti venchurnogo biznesa. Biznesinkubator OmGTU [News of the Venture Business. Business Incubator of Omsk State Technical University]. Available at: http://www.venture-news.ru/ infrastructure/29700-biznes-inkubator-omgtuomskaya-oblast.html (accessed April 20, 2015).

24. OAO Kurganskiy oblastnoy tekhnopark. Natsionalnoe sodruzhestvo biznes-angelov [OJSC Kurgan Regional Technopark. National Commonwealth of Business Angels]. Available at: http://technopark45. $\mathrm{ru} / \mathrm{main} /$ investoru/business-angels (accessed April 20, 2015).

25. Osipov Yu.M. Osnovy teorii khozyaystvennogo mekhanizma [Fundamentals of the Economic Mechanism's Theory]. Moscow, Izd-vo MGU, 1994. $368 \mathrm{p}$.

26. Ozhegov S.I. Slovar russkogo yazyka: 70000 slov [Dictionary of Russian Language: 70000 Words]. Moscow, Russkiyyazyk Publ., 1990.352 p. 


\section{РЕГИОНАЛЬНАЯ ЭКОНОМИКА}

27. Rossiyskaya korporatsiya nanotekhnologiy (ROSNANO) [Russian Corporation of Nanotechnologies (RUSNANO)]. Available at: http://www.admoblkaluga.ru/ upload/mineconom/innovacii/konkyrci/nanocentr/ koncepciya.pdf(accessed April 20, 2015).

28. Sankt-Peterburgskiy akademicheskiy universitet - nauchno-obrazovatelnyy tsentr nanotekhnologiy RAN [Saint Petersburg ACADEMIC UNIVERSITY - Scientific and Educational Center of Nanotechnology, RAS]. Available at: http://www. spbau.ru/infrastructure/centers/collective about (accessed April 20, 2015).

29. Tekhnicheskaya laboratoriya (nauchnoproizvodstvennyy tsentr) [Technical Laboratory (R\&D
Center)]. Available at: http://www.techlab.ru/about. (accessed April 20, 2015).

30. Tekhnopark. Kubanskiy gosudarstvennyy universitet [Technopark. Kuban State University]. Available at: http://www.kubsu.ru/Science/technopark (accessed April 20, 2015).

31. Tsentr konsaltingovykh proektov [Center of Consulting Projects]. Available at: http://www.itmurman.ru (accessed April 20, 2015).

32. Tsentr upravleniya finansami. Innovatsionnaya infrastruktura [The Centre of Financial Management. Innovation Infrastructure]. Available at: http:/www.centeryf.ru/data/stat/Innovacionnaya-infrastruktura.php (accessedApril 21, 2015).

\section{РАЗВИТИЕ ИНФРАСТРУКТУРЫ КАК УСЛОВИЕ СОВЕРШЕНСТВОВАНИЯ МЕХАНИЗМА СТИМУЛИРОВАНИЯ ИННОВАЦИОННОЙ ДЕЯТЕЛЬНОСТИ (НА ПРИМЕРЕ СУБЪЕКТОВ ЮФО)}

\section{Надежда Николаевна Лебедева}

Доктор экономических наук, профессор кафедры экономической теории и экономической политики, Волгоградский государственный университет lebvolgograd@rambler.ru, htes@volsu.ru просп. Университетский, 100, 400062 г. Волгоград, Российская Федерация

\section{Ирина Сергеевна Аверина}

Кандидат экономических наук, старший преподаватель кафедры экономической теории и экономической политики, Волгоградский государственный университет averina-irina@mail.ru, htes@volsu.ru просп. Университетский, 100, 400062 г. Волгоград, Российская Федерация

\section{Юлия Владимировна Задорожнева}

Кандидат экономических наук, старший преподаватель кафедры экономической информатики и управления, Волгоградский государственный университет j_zadorozhneva@mail.ru, econinform@volsu.ru просп. Университетский, 100, 400062 г. Волгоград, Российская Федерация

Аннотация. Рассмотрено понятие механизма стимулирования инновационной деятельности, представляющего собой систему, состоящую из субъектов, имеющих свои цели; формальных норм (законодательство); неформальных норм и правил (деловая культура, принятая в экономическом сообществе); стимулов и ограничений (экономического и неэкономического характера). Уточнено понимание инфраструктуры как условия действия механизма стимулирования инноваций. Проведено сопоставление рейтинговых оценок (по методике НАИРИТ) инновационной активности субъектов Южного федерального округа (ЮФО) и выявлены значимые несоответствия. Предложен сравнительный анализ основных существующих инфраструктурных элементов иннова- 


\section{РЕГИОНАЛЬНАЯ ЭКОНОМИКА}

ционной сферы (Краснодарского края, Волгоградской и Ростовской областей), на основании которого сделаны выводы об их достаточности или недостаточности в различных субъектах макрорегиона. К негативным тенденциям развития инновационной инфраструктуры относятся: отсутствие единой информационно-аналитической базы и системы продвижения и поддержки инновационных проектов; отсутствие в официальных источниках консолидированных данных для оценки уровня развития инновационной инфраструктуры региона; недостаточность и необходимость развития таких элементов, как кластеры и научно-технологические парки, фонды поддержки и создание разветвленных сетей центров коллективного пользования. Проведен сравнительный анализ ряда основных показателей, характеризующих инновационную активность субъектов. Исходя из анализа и выявления отсутствующих инфраструктурных элементов инновационной системы, а также сравнения показателей инновационной активности представлены направления ее совершенствования (научно-инвестиционное, информационно-аналитическое, организационно-коммуникационное) с целью повышения эффективности действующих механизмов стимулирования новаторства в регионах. Научно-практическая значимость работы представляется в дальнейшем использовании ее положений и выводов в качестве дополнительного теоретико-методического обоснования научных разработок в области исследований механизмов стимулирования инновационной деятельности, а также для совершенствования последней в рамках инновационной политики органов государственной власти при определении стратегических приоритетов регионального развития.

Ключевые слова: инфраструктура, элементы инфраструктуры, механизм, стимулирование, инновационная деятельность, проблемы, перспективы. 